\title{
Hospitality Management Education in Ghana : A Case Study of Ho Polytechnic
}

\author{
Esther Theresa Appaw-Agbola ${ }^{1}$, Stephen Afenyo Dehlor ${ }^{2}$ \\ ${ }^{1}$ Department of Hospitality and Tourism Management Ho Polytechnic, Ho, Ghana \\ Email:appawth@yaboo.com \\ ${ }^{2}$ Regional Maritime University, Accra, Ghana \\ Email:Sa402@le.ac.uk
}

\begin{abstract}
The present study aims to examine the hospitality management education system in Ghana and report the initial findings of a qualitative research undertaken for an assessment of the hospitality education system. The views of graduates and students were gathered through in-depth interviews on the hospitality education that they have received. The findings of the study show that the curriculums used by hospitality students in the Polytechnics are overloaded with non-hospitality related subjects. Most of the interviewees felt that they have gained adequate theoretical knowledge and practical skills in the area of food production operation, food and beverage service with little practical knowledge in other subjects. The implication is if the current curricula run by departments of hospitality in the Polytechnics are not reviewed on timely bases, hospitality management graduates from Polytechnics may not meet the needs of industries in this $21^{\text {st }}$ century.
\end{abstract}

Keywords: Training; hospitality management; education; qualitative research; curriculum.

\section{Introduction}

The responsibility for developing serviceoriented human resources lies not only with the hospitality organisations but also with the structure of a country's hospitality management education delivery. For customers to be satisfied through the delivery of quality services by skilled and competent staff, an effective hospitality education system needs to exist.

A well-defined structure will provide organisations with employees who have the potential to become quality leaders. Two decades ago, a large number of authors contributed articles to tourism management which examined the issues of hospitality and tourism education (Richards and Ryan, 1999). Research shows that, in order for hospitality education to be strengthened in the developing countries, it is necessary for developing countries to focus on the directions in which hospitality studies might progress (Gamble 1992; Cooper et al, 1992; Rutter 1993). Buam (2000) argues that education is for professionals and training is for the artisan and the unskilled. According to Buam, by the end of the 20th century, it had been widely recognised that education could not be considered as a finite and terminal activity, and training too could not be considered as a strictly on-the-job, on-going, non-terminal process.

The reason is initial qualifications will no longer last throughout a lifetime's career; the business (world) demands continually higher levels of personal performance efficiency and effectiveness. Hence, the education and training of professionals, in whatever discipline, is a continuing and a lifelong process. To retain competitive edge, professionals must recognise this challenge of change and make the commitment constantly to upgrade their knowledge and skills (Ford \& Le Bruto, 1995). Harris (2006) proposes that both the educational establishments and employers seriously need to consider this development of lifelong learning. Moreover, Haywood (1989) argues that continuous professional development aims at constant upgrading of knowledge and updating of professional skills throughout an individual's working life and hence can be used for the implementation of the concept of lifelong learning. 


\subsection{The need for hospitality management education}

Education is about change and about choice. The increase of one's knowledge, understanding and skills, produces one's ability to influence the surrounding environment. This ability allows the individual or group to become controllers of change, rather than victims of it (Okeiyi, 1994).

Empowerment through education results in committed students who bring decision-making skills and enthusiasm (Iverson, 1995). Furthermore, Ivan (2000) states that, the greater and varied the skills of the individual; the better the person is in terms of personal skills, individuality and use for the organisation.

In the case of hospitality industry, which is characterised by a rapidly changing business environment, those who do not have access to opportunities to learn are deprived of choice, and the ability to contribute to the further development of the industry (Gaiko 1995). According to Gaiko, most governments, including the Ghana government and private bodies, have assisted in the development of formal hospitality and tourism education.

Some emphasize vocational training through apprenticeships; others develop an academic approach to hospitality management and the remaining aim to combine both the academic and the vocational elements (Hofmann 1998). Umbreit (1992) explains that the key outcomes expected through hospitality education are attainment of service quality; employee empowerment through well-educated staff at all levels, effective relationship marketing; teamwork within hospitality organisation and upgrading of operations through hospitality standards.

Umbreit (1992) further argues that, as the barriers on trade and communication continues to be broken down in the 21st century, the industry is provided with limitless opportunities and how established tourism destinations like Ghana should harness these opportunities? This brings some questions to the fore: Which organisations will be successful and why is this constantly changing, competitive tourism business world? The increasing influx of tourists from all walks of life has placed a greater demand upon the Ghana tourism industry, both in volume and standards.

The impact of this has led to the need for greater professionalism within the Ghana hospitality industry which is characterised by a very large, medium, small hotels and family owned poorly managed hotels.

Professionalism is a balance between the provisions of efficient services, while good financial results are maintained (Partlow, 1996). Thus, Professionalism can be achieved by providing an organisation culture that treats staff and customers with civility and respect, and by the creation of policies, systems and working practices which achieve these objectives (Huczynsk \& Buchanan, 1991). The need to maintain and improve an effective hospitality management education system in Ghana is therefore, important and more widely recognised.

\subsection{Hospitality education in Ghana}

Tourism and hospitality education in Ghana started in 1990s since the government of Ghana realized the immense contributions that tourism makes to the economic development of the country. The rapid tourism development in Ghana since then has forced the Ghana government to redefine its tourism education policy at tertiary, vocational and technical level.

The Polytechnic started hospitality and tourism education in Higher National Diploma (HND) in 1993 to date. In Ghana, the National Curriculum and Course Specification (the National Syllabus for HND in Hospitality and Tourism Management) was prepared at the request of the Ministry of Higher Education. It became necessary because of global change, technology and the demand for qualified personnel.

Thus, it was also necessary for the implementation of the government's education reform programme that would make Ghana selfsufficient in manpower to take care of her professional needs as well as to make her nationals marketable in countries other than Ghana. The general aim of the curriculum is to produce qualified graduates with requisite knowledge and skills for managerial/supervisory positions in the hospitality industry.

A critical review of foreign hospitality curriculum and the curricula run in the Polytechnics show a great disparity in the hospitality training institutions in Ghana. For example, language programmes with strong service orientation; second, economics and management programmes such as tourism management, hotel management, time management, total quality management, innovation and entrepreneurship and finance. Skill-oriented programmes which have become part of the National plan for Polytechnics are missing out in the curriculum run in the Polytechnics in Ghana while in 
developed countries these subjects are part of the curriculum.

In addition, intensive internship programmes for at least six months are part of the curriculum used in developed countries. For instance, Eaton (1997), states that the internship component is much more important for foreign tourism institutions.

Moreover, Christou (1991) argues that, because of the limited laboratory facilities, the curriculum in institutions of higher learning generally places more emphasis on classroom instruction and de-emphasizes skill development. Thus, students have virtually no laboratory experience prior to entering the industry as interns. Fresh graduates have to learn the skills from scratch and are unproductive during their early stages of employment.
It is expected that tourism will become the number one foreign exchange earner by the year 2015 . The government of Ghana projects the tourism sector to generate an estimated income of US $\$ 274$ million and employ a total of 307,000 persons by the year 2012 (Ghana Tourist Board, 2011). The influx of international tourists and businessmen into Ghana has increased significantly in the last 20 years. It is expected that the growth will continue, in particular, following the hosting of World Tourism Day and Ghana's exploitation of oil and gas in large quantities. Table one represents data from selected tourist sites as in appendix 1

Appendix

An analysis of Ghana's Tourism receipt from 7 Eco-tourism sites for 2009

\begin{tabular}{llcc}
\hline REGION & ECO-TOURISM & ARRIVALS & REVENUE \\
& SITES & & \\
\hline CENTRAL & Kakum National Park & 150,884 & $259,878.99$ \\
NORTH & Mole National Park & 14,809 & $127,551.76$ \\
CENTRAL & Cape Coast Castle & 76,1009 & $112,316,70$ \\
CENTRAL & Elmina Castle & 74,293 & $92,644.70$ \\
WESTERN & Nzulezu & 8,720 & $41,986.40$ \\
B/A & Boabeng Fieman & 18,1555 & $32,330.86$ \\
VOLTA & Tafi Atome Monkey & 10,468 & $16,686.11$ \\
& Sanctuary & & \\
\hline
\end{tabular}

Tourists arrivals increased from 428,533 in 2005 , recording a tremendous growth rate to date.

The national average occupancy rate is at 94 percent (GTB, 2010).

\section{Problem statement}

Tourist arrivals have increased in the country for the past decade. As a result, the government of Ghana has mandated the institutions of hospitality and tourism related programmes in the polytechnics. Meanwhile, Goldsmith and Smirli (1995) report an analysis of hospitality education in developing countries with a particular reference to the problems of their curriculum.
The main objective of the research is to examine hospitality and tourism related education in Ghana (Curriculum), specifically in Polytechnics using hospitality and tourism management students in Ho Polytechnic.

\subsection{Objectives of the study}

1. To review the hospitality and tourism management curriculum in selected tourism institutions in Ghana. 
2. To evaluate the views of the graduates and students of Ho Polytechnics pursuing hospitality and tourism management programmes.

3. To put forward policy implications for overall improvement of the curriculum in public and private tourism and hospitality institutions in Ghana.

\section{Methodology}

The information provided in this study is entirely based on in-depth interviews conducted with hospitality and tourism management students in Ho Polytechnic. A sample size of 155 second and third year students of Higher National Diploma (HND), Bachelor of Technology (Btech) degree students and graduates working in hotels were used. Since the study was directed to review the curriculum in Polytechnics, the stratified random sampling technique was applied to obtain a representative sample size.

The data were obtained through personal indepth interviews and were qualitative in nature. The interviews were conducted by the use of an informal conversation method with no structured questions designed to gather information from respondents rather than to statistically generalize from a larger sample. The chosen form of interviews was that of free response which gave the respondents a great deal of freedom in answering questions arising from the general points of discussion. All interviews were conducted according to the "funnel" technique Chisnal (1989). A list of points, which the interviews should cover, was prepared in advance. These points evolved around the following themes: the skills and knowledge gained from studies; evaluation of the industrial placement periods; the quality of the educational preparation for the reality of the workplace; the content of the curriculum, and other issues that were raised by the respondents. The researchers guided all interviews, which allowed for adequate coverage of all the relevant themes.

\section{Results discussion}

One hundred and fifty five (155) respondents are selected for the study. Fifty-nine (59) interviewees were in full-time employment in the hospitality industry. These interviewees represented the total number of the 2010 graduates working in all three-star hotels regardless of their size and all two-star hotels with 150 bedrooms or more.
Fifteen are unemployed but since their graduation, they have worked in hotels on seasonal bases. Eighty one (81) respondents represent second and third year HND and B. Tech students of the Department of Hospitality and Tourism Management. One hundred and twenty five (125) respondents are between 22 and 26 years of age while thirty (30) are between 26 and 30 years old. The respondent's views about the hospitality education that they had received, one of the most interesting outcomes of the survey, are that there were no significant differences between the responses from the respondents who completed and those who were about to complete.

Although limits to the range of the responses are not imposed and Likert scales are not used, it is possible to group, in percentages, a number of responses that show a large degree of conformity. Findings reveal that, majority of the interviewees felt that the curriculum used by hospitality and tourism students are over loaded and practical training is based on only some component. Adequate theoretical knowledge and practical skills are gained in the area of food production operation, food and beverage service. They argue that the theory content of accommodation or housekeeping services, front office operations and food technology are too much and the practical aspect is very minimal.

It is also revealed that eighty two (82\%) per cent of the final year students of HND argue that the coverage of food production and food and beverage service was over emphasised, front office operation and accommodation operation could have been covered in greater depth particularly the practical component. The area of information technology studies and skills in other subjects were also agreed to have been covered very poorly, owing to inadequate hardware and poor tuition. Most of the interviewees $(78 \%)$ wish to see radical improvements in this area in the future.

On the issue of knowledge and skills in foreign language, all the interviewees agree that all programmes studied were delivered in English. However, more than (95\%) percent felt that their skills in other languages (French) were not adequate for the requirements of their work environment. Majority of the interviewees both final and second year students $(88 \%)$ present criticised the quantity and the quality of the courses' coverage of business administration topics such as purchasing and costing, accounting, management of human resources, organisational theory, and economics. They argued that some of the subjects were not part of the 
curriculum.

An unexpected outcome of the interview showed that all interviewees admitted they did not even know what Total Quality Management (TQM) was. A few said that they are familiar with the concept in theory but not in practice. Accountancy was the only business administration topic that they felt they gained essential knowledge through their study; the majority would have preferred more in-depth course coverage in this area. The development of transferable soft skills such as Customers' Complaints and Customer Relation was judged not to have been covered satisfactorily.

Most interviewees (79\%) agreed that the development of written communication, critical analysis, logical thinking, problem solving and computing skills was quite satisfactory. However, the development of team work, presentation skills, organisational skills, leadership skills and motivation skills had unsatisfactory responses. Most of the interviewees expressed their views that a number of essential soft skills, including time management, stress management and personnel skills like, discipline and interviewing, were not included at all in their course programmes and that they were also not taught how to handle internal issues in their various work environments).

On the issue of industrial placement, the interviewees agreed that they had freedom of choice for placement but they had limited time for practice therefore they did not gain much industrial experience before they returned to school.

They admitted that the industrial placement was, to an extent, an effective way of putting the acquired knowledge and skills to a real- life test. The majority of the interviewees (91\%) agreed that by the end of the placement phase, they had a better understanding of some of the hospitality and tourism jobs. They also added that although they were not psychologically prepared for work responsibilities, they gained valuable experience from being in a real-life working environment.

Findings reveal that graduates who completed and are working in the industry agreed that when they were employed after graduation they were quite confident in food production and food service but faced challenges in other subject areas. According to graduates in full-time or seasonal jobs in the industry, most of the on-the-job training provided by their employers was about hospitality operations and not about management. A major source of concern for most of them was the lack of in-depth knowledge of relevant legislation. In addition, in hotels, the mostwidely mentioned sources of disappointment include: underpayment, long hours of work, discrimination in promotion and development and the feeling that they were seen by companies as cheap labour because they are not regarded as people who have been trained to meet the needs of industries.

Majority of the graduates (86\%) admitted that the curriculum must be tailored to meet the needs of industry. They emphasised that on the job training and supervisory skills were kept to a minimum, and they had very limited opportunities to put into practice their knowledge and skills acquired. They also argued that combination of unsatisfactory working conditions and the lack of management training and experience resulted in low morale and reduced motivation.

\section{Conclusions}

Tourism and hospitality education in Ghana started in 1990s when the government of Ghana realized the immense contributions that tourism makes to the economic development of the country. The general aim of the curriculum is to produce qualified graduates with requisite knowledge and skills for managerial/supervisory positions in the hospitality industry. However, the findings revealed that the graduates who pursue hospitality management programmes in the Polytechnics in Ghana are not fully prepared for the requirements of the hospitality and tourism industry. Therefore, it could be assumed that the provision of the tertiary hospitality and tourism management education in Polytechnics in Ghana up to the degree and HND levels do not fully meet the current needs of industry. There is a gap between competence of graduates and industrial needs and there is the notion that the gap would increase in future because of industry dynamism. (If in future the existing system will remain as it is the gap between the industry's needs and the results achieved by the education will probably be increased as a result of these findings, a number of broad issues arise for hospitality and tourism education in Ghana.

The following implications may be useful for stakeholders to consider in improving the curriculum at all hospitality and tourism related institutions. The research described here could be used as a starting point for a major re-assessment of the hospitality education system, for the revamping of the relevant curricula in the Polytechnics and other tourism related institutions. The forms of teaching and 
learning also need to be revised. New forms of learning such as role-playing, case studies, presentation, games and simulations could be fully exploited for the benefit of both the students and the industry. The curriculum should be examined. If it is possible, some subjects such as Engineering, Maintenance and African studies are totally removed or could be taught using different approaches.

Many more laboratories could be built to cater for practical work rather than too much emphasis on the theory. Polytechnics should arrange for industrial placements for their students and the period extended to six months. Subjects such as Innovation and Entrepreneurship and Service Marketing should be taught throughout six semesters instead of one semester.

\section{Limitations}

No study can be error free (Hug, 2005). The study covered hospitality and tourism students from Ho Polytechnic. These studies could be replicated in other Polytechnics and other tourism related institutions. In-depth studies may be conducted to evaluate teaching strategies of the various hospitality subjects and their impact on student's performance.

\section{References}

Baum, T., (1995). Competencies for Hotel Management: Industry Expectations of Education. International Journal of Contemporary Hospitality Management, Vol. 2 No 4,pp13-15.

Baum, T., (1995). Managing Human Resources in the European Hospitality Industry: A Strategic Approach. London: Chapman \& Hall, London.

Casado, M. A., (1992). Higher Education Hospitality Schools: Meeting the Needs of the Industry. Hospitality and Tourism Educator, Vol. 4 No2, pp. 1011.

Chisnal, P. M., (1989). Marketing Research, McGrawHill, London.

Christou, E., (1997). Researching Tertiary Hospitality Education: System's Assessment, Tourism and Economy, Vol. 4, No. 2, pp. 10-12

Cooper, C., Scales, J. W., and Westlake, J., (1992). The Anatomy of Tourism and Hospitality Educators in the UK, Tourism Management, Vol. 5 No. 2, pp. 3442.
DiMicelli, P., (1998). Blending Theory and Practical Experience: A Hands-on Approach to Educating Hospitality Managers, Journal of Hospitality and Tourism Education, Vol.10, No.1, pp 32-36.

Downey, J. F., and DeVeau, L., (1988). Hospitality Internships: An IndustryView; Cornell Hotel and Restaurant Administration Quarterly, Vol. 29, pp1820.

Eaton, J. and Christou, E., (1997). Hospitality Management Competencies for Graduate Trainees: Employers' Views, Journal of European Business Education, Vol.7, No.1, pp60-68.

Ferreira, R. R., (1992). A Review of Case Analysis and Simulation for Use in Hospitality Management Education, Hospitality and Tourism Educator, Vol.4, No.2, pp.16-20.

Fitzgerald, M. J., and Cullen, T. P., (1991). Learning through a Real World Experience, The Cornell Hotel and Restaurant Administration Quarterly, No.85-88.

Ford, C. R., and LeBruto, S. M. (1995). Management education in the USA: How Much Practical Hotel Management Education is Necessary? International Journal of Contemporary Hospitality Management, Vol.7, No.5, pp.8-9

Gaiko, S. S., Kavanaugh, R. R., and Bokorney, G. B. (1995). Establishing a Hospitality Education Program for Japanese Students. Hospitality and Tourism Educator, Vol.7 No.1, pp. 60-62.

Gamble, P. R., (1992). The Educational Challenge for Hospitality and Tourism Studies, Tourism Management, No.6-1.

Goldsmith, A. and Smirli, E., (1995). Hospitality Education in Greece: The Supply of Training on Rhodes. Tourism Management, Vol.16, No.8, pp. 619-623.

Goodman, J. R and Sprague, L. G., (1991). The Future of Hospitality Education: Meeting the Industry's Needs, The Cornell Hotel and Restaurant Administration Quarterly, Vol. 32 No.2, pp.66-69.

Harris, K. J. (1997) Opinions of Training Methods Used in the Hospitality Industry: A Call for Review, International Journal of Hospitality Management. 
Haywood, K. M., (1989). A Radical Proposal for Hospitality and Tourism Education, International Journal of Hospitality Management, Vol.8 No.4, pp.259-260.

Hofmann, S., (1998). New Opportunities for Tourism and Tourism Education, Tourism and Economy, No. 115-116.

Huczynski, A., and Buchanan, D. (1991). Organisational Behaviour, Prentice-Hall, Hempsted.

Iverson, K., (1995). Student Empowerment: Revitalize Hospitality Education with the Total Quality Management Process, Hospitality and Tourism Educator, Vol.7, No.2, pp.56-58.

LeBruto, S. M. and Murray, K. T. (1995). The Educational Value of Captive Hotels, The Cornell Hotel and Restaurant Administration Quarterly, August, No.72-79.

Ivan, D., (1991). The Hospitality Industry; Industrial Placement and Personnel Management, Service Industries Journal, Vol.11, No.1, pp. 63-74.

Okeiyi, E., and Finley, D., and Postel, R. T., (1994). Food and Beverage Management Competencies: Educator, Industry and Student Perspectives, Hospitality and Tourism Educator, Vol. 6, No.4, pp.37-40.
Partlow, C. G., (1996). Human Resources Practices of TQM Hotels, The Cornell Hotel and Restaurant Administration Quarterly, Vol. 37 No.1, pp.67-77.

Pavesic, D. V.,(1993). Hospitality Education: Curricular and Programmatic Trends. Hospitality Research Journal, Vol.17 No.1, pp.285-294.

Petrillose, M. J., and Montgomery, R. (1998). An Exploratory Study of Internship Practices in Hospitality Education and Industry's Perception of the Importance of Internships in Hospitality Curriculum, Journal of Hospitality and Tourism Education, Vol.9, No.4, pp. 46-51.

Pizam, A., (1995). Who is the Customer in Hospitality Education? International Journal of Hospitality Management, Vol.1, No.3, pp. 215-216.

Richards, G., (1998). A European Network for Tourism Education, Tourism Management, Vol.19, No.1, pp.1-4.

Rutter, D., (1993). Catering Education in Britain and Germany, Tourism Management, No.7 pp.70-73.

Umbreit, W. T., (1992). In Search for Hospitality Curriculum Relevance for the 1990s, Hospitality and Tourism Educator, Vol.15, No.1, pp.71-74. 